\title{
Correction to: Serum HBV RNA quantification: useful for monitoring natural history of chronic hepatitis B infection
}

Yayun Liu ${ }^{1 \dagger}$, Meng Jiang ${ }^{1 \dagger}$, Jianya Xue ${ }^{1}$, Hongli Yan ${ }^{2^{*}}$ and Xuesong Liang ${ }^{1 *}$

\section{Correction to: BMC Gastroenterol}

https://doi.org/10.1186/s12876-019-0966-4

Following publication of the original article [1], the author reported an error in the "Abstract", under the "Methods" section. The sentence "inactive chronic hepatitis $\mathrm{B}(\mathrm{ICH}, \mathrm{n}=58)$ and $\mathrm{HBeAg}$-negative immune reactive hepatitis $(\mathrm{ENH}, \mathrm{n}=77)$ " should be change to "inactive chronic hepatitis $\mathrm{B}(\mathrm{ICH}, n=77)$ and $\mathrm{HBeAg}$-negative immune reactive hepatitis $(\mathrm{ENH}, n=58)$."

Received: 30 April 2019 Accepted: 30 April 2019

Published online: 10 May 2019

\section{Reference}

1. Liu, et al. Serum HBV RNA quantification: useful for monitoring natural history of chronic hepatitis B infection. BMC Gastroenterol. 2019;19:53. https://doi.org/10.1186/s12876-019-0966-4.

\footnotetext{
*Correspondence: 13321805629@163.com; hongliyan@smmu.edu.cn; liangxuesong2000@163.com

†Yayun Liu and Meng Jiang contributed equally to this work.

${ }^{2}$ Department of Reproductive Medicine Center, Changhai Hospital, Second

Military Medical University, 168 Changhai Road, Shanghai 200433, China

'Department of Infectious Diseases, Changhai Hospital, Second Military

Medical University, 168 Changhai Road, Shanghai 200433, China
}

(c) The Author(s). 2019 Open Access This article is distributed under the terms of the Creative Commons Attribution 4.0 International License (http://creativecommons.org/licenses/by/4.0/), which permits unrestricted use, distribution, and reproduction in any medium, provided you give appropriate credit to the original author(s) and the source, provide a link to the Creative Commons license, and indicate if changes were made. The Creative Commons Public Domain Dedication waiver (http://creativecommons.org/publicdomain/zero/1.0/) applies to the data made available in this article, unless otherwise stated. 